\title{
Health Effects of Toxic Cyanobacteria in U.S. Drinking and Recreational Waters: Our Current Understanding and Proposed Direction
}

\author{
Timothy G. Otten • Hans W. Paerl
}

Published online: 21 January 2015

(C) Springer International Publishing AG 2015

\begin{abstract}
Cyanobacterial-derived water quality impairment issues are a growing concern worldwide. In addition to their ecological impacts, these organisms are prolific producers of bioactive secondary metabolites, many of which are known human intoxicants. To date only a handful of these compounds have been thoroughly studied and their toxicological risks estimated. While there are currently no national guidelines in place to deal with this issue, it is increasingly likely that within the next several years guidelines will be implemented. The intent of this review is to survey all relevant literature pertaining to cyanobacterial harmful algal bloom secondary metabolites, to inform a discussion on how best to manage this global public health threat.
\end{abstract}

Keywords Cyanobacterial harmful algal blooms · Toxin · Secondary metabolite $\cdot$ Water quality

\section{Introduction}

Cyanobacteria, commonly referred to as blue-green algae, are a phylum of photosynthetic bacteria that are ubiquitous in freshwater, estuarine and marine waters [1]. Many of the

This article is part of the Topical Collection on Water and Health

Electronic supplementary material The online version of this article (doi:10.1007/s40572-014-0041-9) contains supplementary material, which is available to authorized users.

T. G. Otten $(\bowtie)$

Department of Microbiology, Oregon State University,

226 Nash Hall, Corvallis, OR 97331, USA

e-mail: ottent@onid.orst.edu

H. W. Paerl

Institute of Marine Sciences, University of North Carolina at Chapel

Hill, Morehead, NC 28557, USA genera in this phylum are positively buoyant and, when conditions are appropriate, they can "bloom" as dense, paint-like scums on the water surface [2]. Global climate change, particularly rising temperatures [3] and increasing atmospheric $\mathrm{CO}_{2}$ concentrations $[4,5]$, nutrient over-enrichment due to fertilizer misuse and wastewater discharges [6] and hydrologic modifications to the natural environment (eg, damming rivers) [7], are all expected to contribute to an increase in the frequency and magnitude of cyanobacterial harmful algal blooms (CHABs). Many of the CHAB genera produce potent toxins that are a growing public health concern due to their widespread presence in temperate and tropical waters and their history of poisoning events of wild and domestic mammals, birds, and humans, which have been well documented over the past $100+$ years [8-11]. Additionally, there are concerns that as CHABs become more severe due to climate change and eutrophication (nutrient over-enrichment), a positive feedback loop may select for toxigenic (microcystinproducing) populations over their nontoxic counterparts in response to augmenting oxidative stressors within the local bloom environment [12].

Human exposures to cyanobacteria and/or their harmful metabolites can occur in a number of ways. The most likely exposure is by recreating on waters where cyanobacterial accumulations are present. Skin contact with blooms may result in acute dermatitis and inhalation of water spray containing cyanobacteria may exacerbate pre-existing respiratory conditions such as asthma [13]. While exceedingly rare, hospitalizations and human fatalities have been linked to recreational exposures to CHABs $[14,15]$. However, direct ingestion, either through drinking water or by consuming contaminated seafood-due to toxin biomagnification, remains the primary exposure route of concern [16]. Reporting of algal bloomassociated disease outbreaks is not currently mandatory in the U.S., although there are channels through which reports can be voluntarily submitted, including the Center for Disease 
Control's (CDC) Waterborne Disease and Outbreak Surveillance System (WBDOSS) and the Harmful Algal BloomRelated Illness Surveillance System (HABISS). Data from these networks were reviewed in a recent study that identified 11 freshwater lake algal-bloom associated disease outbreaks (61 illnesses) from 2009-2010, based on reports from 3 states (New York, Ohio, and Washington) [17]. The most common symptoms were rash or skin irritation, gastroenteritis and respiratory distress - none were fatal. Until a national disease registry is established to document symptoms of cyanotoxicosis, and because recreational exposures usually involve little to no water ingestion, pets, livestock, and wild animals will continue to serve as one of our better, albeit unfortunate, sentinels for toxic algal bloom events in surface waters that are not routinely monitored [18, 19]. Fortunately, an experimental treatment for the successful treatment of acute microcystin intoxication in a dog was recently reported [20•]. The treatment relied upon a combination of supportive care and oral dosages of the bile acid sequestrant cholestyramine, which is thought to promote excretion of the toxin in the animal's feces. While this therapy remains experimental, it does provide veterinarians with a novel treatment option that was previously unknown.

In the developed world, where drinking water treatment processes are commonplace, there have only been a few documented outbreaks of acute cyanotoxicosis in humans. One outbreak occurred in a health clinic in Brazil when a point-of-use filtration system failed, resulting in high concentrations of microcystin being administered to dialysis patients who developed acute renal failure resulting in high mortality rates [21]. Another outbreak occurred in Australia when a cyanobacterial bloom in a local drinking water reservoir was treated with an algaecide, releasing large amounts of cylindrospermopsin into the drinking water [22]. However, there are a number of reasons why these types of events are so rare even though cyanobacteria are so prevalent in surface water, for example: (1) drinking water withdrawal pipes are placed below the thermocline and/or photic zone in reservoirs where cyanobacteria are less abundant; (2) intact cells (which contain the majority of toxin) are sedimented out of the water column using coagulants and flocculants, which have been shown to remove anywhere from $62 \%-99 \%$ of cyanobacterial cells [23], although dissolved air floatation tends to be most efficacious [24, 25]; and (3) physical (UV) and chemical $\left(\mathrm{O}_{3}>\mathrm{MnO}_{4}>\mathrm{HOCl}>\mathrm{NH}_{2} \mathrm{Cl}\right.$ or $\left.\mathrm{ClO}_{2}\right)$ disinfectants, ranked by their effectiveness, can also be highly effective at inactivating dissolved (extracellular) toxin loads depending on the dose, $\mathrm{pH}$ and contact time [26, 27]. Additional treatment processes, such as filtering through granular activated carbon, will further reduce most dissolved toxins following disinfection [28, 29], although this technique remains undemonstrated for anatoxin-a. While an acute intoxication event always remains a possible threat, it seems that at this time the greater concern may be in answering how chronic, low dose exposures to cyanotoxins impact human health over a lifetime $[30,31]$.

\section{Cyanotoxin Biosynthesis}

The term "cyanotoxin" refers to those known cyanobacterial metabolites capable of negatively impacting human health, of which 5 classes of compounds are widely recognized: microcystin (hepatotoxin), nodularin (hepatotoxin), cylindrospermopsin (cytotoxin/hepatotoxin), anatoxin-a (neurotoxin), and saxitoxin (neurotoxin) [32]. These compounds are produced by combined (hybrid) nonribosomal peptide synthetases (NRPS) and polyketide synthases (PKS), which are large, iterated enzyme modules that use a thiotemplate mechanism to incorporate amino acids into a growing peptide chain $[33,34]$. Recombination events within the adenylation domains of these NRPS/PKS complexes has caused a reduction in substrate specificity, resulting in strain-to-strain variation in the types of toxin congeners that can be produced [35], and these compounds can be further modified (eg, demethylated) and tailored by various enzymes to produce additional isoforms [36]. To date, there are at least 7 recognized structural isoforms of nodularin, 3 of anatoxin-a, 7 of saxitoxin, 3 of cylindrospermopsin and more than 80 of microcystin $[37,38]$. Each of these variants exhibit slightly different bioactive potentials, for example, MC-LR is 6.4-times more toxic than MC-RR, but 8.4-times more toxic than $\left[\mathrm{Dha}^{7}\right] \mathrm{MC}-\mathrm{RR}$ in mice [39].

Of the recognized cyanotoxins, microcystin is the most ubiquitous worldwide [40]. Its widespread distribution is likely due to the fact that the microcystin synthetase $(m c y)$ genes are thought to have been present in all cyanobacteria at one time [41]. While acute, high-dose microcystin exposures have been shown to induce liver hemorrhage due to protein phosphatase 1 and $2 \mathrm{~A}$ inhibition and subsequent hepatocyte deformation [42, 43], chronic, low-dose exposures have been implicated in hepatocarcinoma, tumor promotion and endocrine disruption [44-48]. Nodularins are structurally similar to microcystins, and as such they share similar toxicities and modes of action as microcystins [49, 50]. Cylindrospermopsin is an alkaloid that exerts broad scale cytotoxic effects [51], although it primarily impacts hepatocytes by inhibiting glutathione synthesis, which ultimately leads to cell death and liver hemorrhage [52]. The anatoxins (anatoxin-a, dihydroanatoxin-a and homoanatoxin-a) are a group of neurotoxic alkaloids that potently and irreversibly inhibit acetylcholinesterase within the nerve synapse; which can lead to paralysis and asphyxiation [53, 54]. The genes involved in the biosynthesis of these compounds in diverse cyanobacteria have recently been elucidated [55]. These $3 \mathrm{com}-$ pounds should not be confused with anatoxin-a(s), although 
they all share a similar mode of action, anatoxin-a(s) is a distinct molecule and the genes involved in its biosynthesis remain unknown. Another cyanobacterial neurotoxin, saxitoxin, is one of the agents responsible for paralytic shellfish poisoning [56]. The metabolite selectively blocks voltage-gated sodium channels on nerve cells, inhibiting muscle contraction resulting in a prolonged, relaxed state of paralysis [57]. Unlike the hepatotoxins, which cause physical damage to the liver, cyanobacterial neurotoxins have no established link to cancer formation or endocrinological effects [58].

There is a sixth cyanotoxin-although steeped in controversy - that is worthy of discussion, beta-N-methylaminoL-alanine. BMAA is a nonprotein amino acid [59] that has been shown to cause motor neuron degeneration and has been associated with the formation of progressive neurodegenerative diseases such as amyotrophic lateral sclerosis (ALS), Alzheimer's disease and Parkinson's disease [60]. It has been hypothesized that neurodegeneration occurs when BMAA is mistakenly incorporated into proteins in place of standard amino acids, which results in protein misfolding and collapse [61]. BMAA was first linked to neurodegenerative disease when it was found in the seeds of a cycad (Cycas circinalis) that were identified as a key food ingredient of the native Chamorro population of Guam, whom suffer from 100-fold higher incidence rates of ALS/Parkinson's disease than the rest of the world [62]. Further research identified a cyanobacterial symbiont (Nostoc) living in the roots of the cycad as the BMAA producer and the claim that BMAA could be biomagnified into higher trophic levels [63]. This led to an investigation of diverse cyanobacterial genera and the finding that BMAA was identified in $95 \%$ of cyanobacterial genera screened $(n=21)$ [64]. However, numerous other studies have failed to identify the metabolite in a variety of cyanobacterial genera $[65,66]$ and cycads have been grown in the absence of endophytic cyanobacteria and BMAA concentrations still increased in their roots-casting additional doubt on the cyanobacterial-source theory [67]. It remains uncertain how much of this discrepancy has been due to methodological complications in distinguishing this compound from other similar proteinogenic amino acids, although a recent review of analytical techniques does indicate that liquid chromatography-tandem mass spectrometry (LC-MS/MS) should be utilized in place of other optical methods, which are likely to misidentify or overestimate BMAA concentrations [68]. At present, a thorough review of the scientific literature only really implicates Nostoc spp. as a cyanobacterial genus that may produce BMAA.

Full Genome Sequencing Reveals a Wealth of Secondary Metabolite Pathways

The rapid advances being made in high throughput sequencing and bioinformatics has had a profound effect on our understanding of cyanobacterial physiology and has led to a flourish of sequenced cyanobacterial genomes being deposited into public data repositories like NCBI GenBank in recent years (Fig. 1). Going forward, these data will lead to a better understanding of cyanobacterial evolution and speciation patterns, including the detection of unique gene traits, the phylogenetic distribution of toxin-encoding genes and the identification of novel (putative) operons involved in secondary metabolite biosynthesis for each of these genomes. It is already clear that most cyanobacteria produce a variety of cyclic peptides and other bioactive molecules (eg, alkaloids, lipopeptides, polyketides), many of which exhibit antibiotic, antiviral, antifungal, cytotoxic and/or neurotoxic properties $[69,70]$. The apparent exception to this rule can be found in picoplanktonic cyanobacteria from the oligotrophic open-ocean; the genome sizes in these organisms have been greatly reduced, removing most redundant homologs and metabolically expensive large molecule synthesis pathways [71]. This pattern is hypothesized to be driven by natural selection as a consequence of living in an austere environment (eg, low light, macronutrients and iron) where large metabolic pathways are too expensive to maintain [72]. In contrast, freshwater, estuarine and near coastal environments are resource-rich and cyanobacterial strains isolated from these areas tend to have larger, more complex genomes. In a comprehensive study conducted in 2010 [73], NRPS genes were identified in $75 \%$ of cyanobacterial strains tested $(n=146)$, representing all subsections of the phylum. Adding to the previous study, we screened the genomes of all freshwater bloom-forming cyanobacteria presently available (August, 2014) in NCBI GenBank for NRPS/PKS pathways using the software program antiSMASH 2.0 ('antibiotics and secondary metabolite analysis shell') [74]. For the 48 freshwater $\mathrm{CHAB}$ genomes investigated, NRPS/PKS gene clusters were found in all but 1 strain, and the number of these complexes ranged from 0 to 22 per genome (mean=5.5; median=5.0) (Fig. 2) (Supplemental Table 1). The widespread distribution of NRPS/PKS gene clusters within freshwater cyanobacteria underscore that cyanobacteria are prolific producers of natural products that are often unique from all other microorganisms. While this property makes them very attractive for discovery and development of novel pharmacological agents, the vast number of bioactive peptides in their genetic repertoire poses a significant technical challenge in assessing their toxicological properties and estimating human health risks [75]. Cyanobacteria also produce a diverse array of ribosomallydependent small peptide molecules such as bacteriocins, cyanobactins, terpenes and lantibiotics [76 ${ }^{\circ}$. Table 1 summarizes all of the known bioactive metabolites produced by the most commonly observed freshwater $\mathrm{CHAB}$ genera. 
Fig. 1 High throughput sequencing and genome assembly has resulted in great advances in understanding cyanobacterial genetics as the number of freshwater cyanobacterial genomes deposited into NCBI GenBank continues to accelerate.

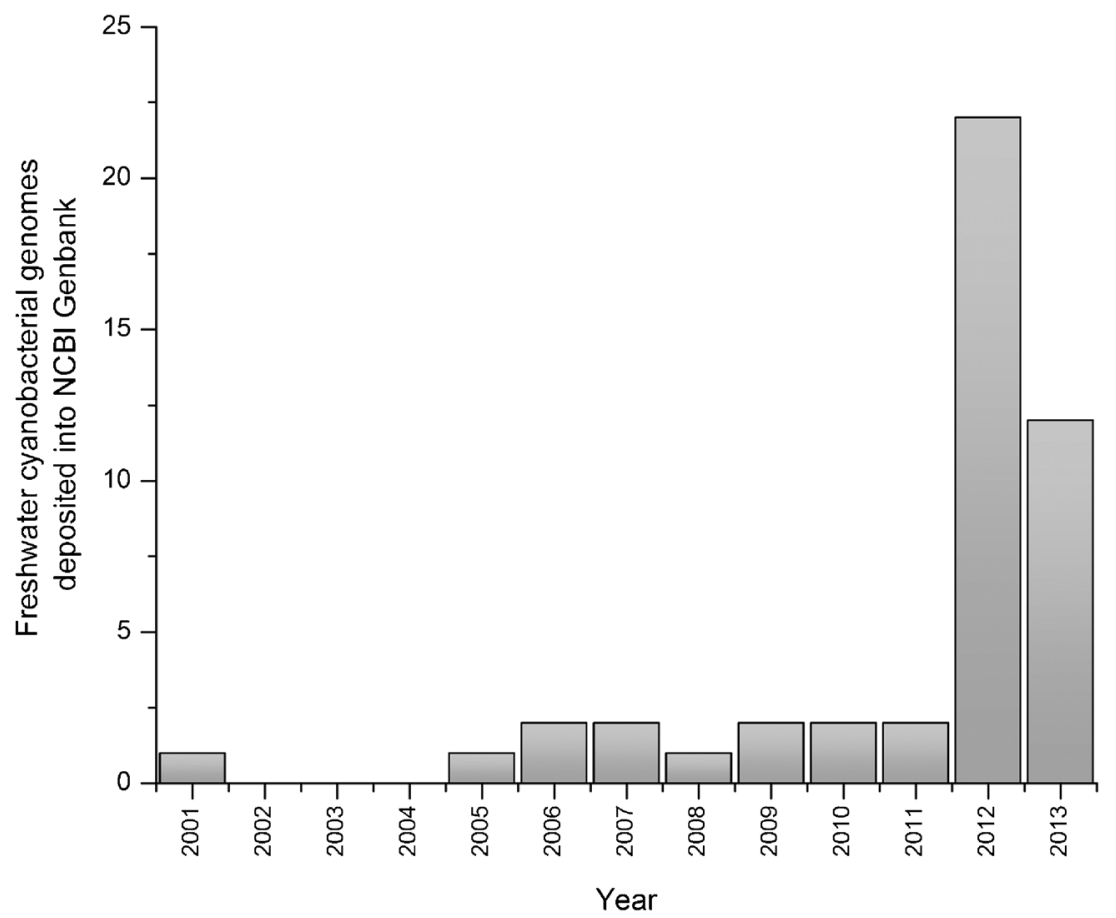

\section{Secondary Metabolite Gene Expression and Metabolomics}

The intracellular and/or ecological roles of secondary metabolites remain largely unknown, although numerous explanations have been offered, which include: defense mechanisms, colony formation, quorum sensing, iron (siderophores), or nutrient scavenging, allelopathy, UV protection and redox homeostasis $[77,78]$. Our inability to clarify the biological roles of these compounds makes it tempting to group them all together as nonessential molecules, since their patchy distribution throughout the phylum suggests they are unlikely to
Fig. 2 Distribution of nonribosomal peptide synthetases (NRPS), polyketide synthases (PKS), and combined hybrid NRPS/PKS based on all currently available genomes (NCBI, August 2014) of the most prevalent bloom forming freshwater cyanobacterial genera identified using the antiSMASH 2.0 analysis platform [74].

Numbers in parentheses indicate the number of genomes analyzed for each genus.

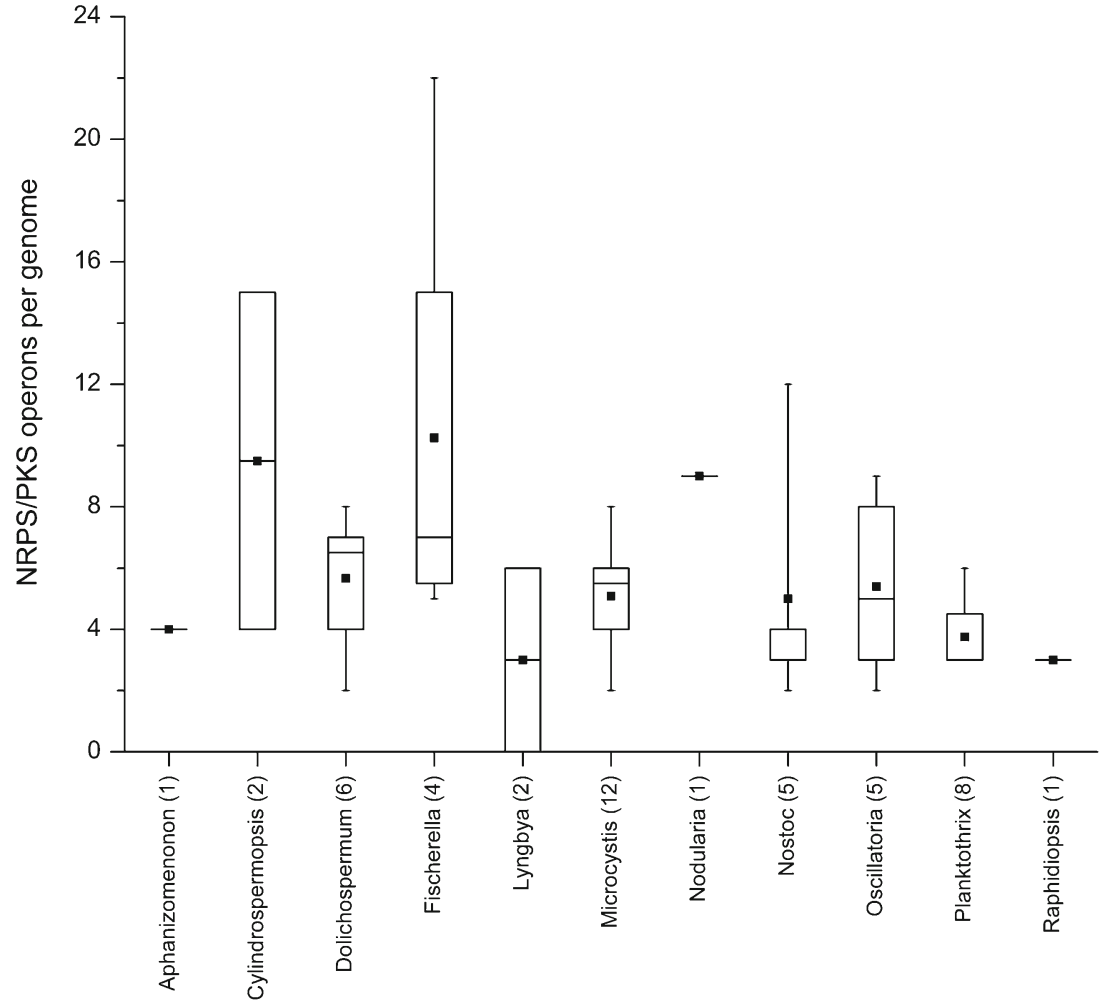


Table 1 Overview of known bioactive secondary metabolites from the most common freshwater bloom forming cyanobacterial genera

\begin{tabular}{|c|c|c|c|c|c|c|c|c|c|c|c|c|c|c|}
\hline Class & Biosynthesis & APHA & CYL & DOL & FISCH & GLO & LYNG & MIC & NOD & NOST & OSCIL & PLANK & RAPH & Ref \\
\hline Aeruginosin & NRPS & & & & & & & $\mathrm{X}$ & $X$ & & & & & {$[106,107]$} \\
\hline Anabaenopeptin & NRPS & $X$ & & $\mathrm{X}$ & & & & $\mathrm{X}$ & $X$ & & & $X$ & & {$[106]$} \\
\hline Anatoxin-a & NRPS/PKS & $\mathrm{X}$ & $\mathrm{X}$ & $\mathrm{X}$ & & & & & & & $\mathrm{X}$ & $\mathrm{X}$ & $\mathrm{X}$ & [106] \\
\hline Anatoxin-a(s) & Unknown & & & $\mathrm{X}$ & & & & & & & & & & {$[106]$} \\
\hline Aplysiatoxins & PKS & & & & & & $\mathrm{X}$ & & & & $\mathrm{X}$ & & & [109] \\
\hline Bacteriocins & Ribosomal & & $X$ & $\mathrm{X}$ & & & & $\mathrm{X}$ & $X$ & $X$ & & & $\mathrm{X}$ & {$[110]$} \\
\hline BMAA & Unknown & & & & & & & & & $X$ & & & & {$[64,65]$} \\
\hline Cyanobactins & Ribosomal & $\mathrm{X}$ & & $\mathrm{X}$ & & & $\mathrm{X}$ & $\mathrm{X}$ & $\mathrm{X}$ & $\mathrm{X}$ & $\mathrm{X}$ & $\mathrm{X}$ & & {$[101]$} \\
\hline Cyanopeptolin & NRPS & & & $\mathrm{X}$ & & & $\mathrm{X}$ & $\mathrm{X}$ & $\mathrm{X}$ & & & $\mathrm{X}$ & & {$[106]$} \\
\hline Cyclamides & Ribosomal & & & $\mathrm{X}$ & & & $\mathrm{X}$ & $\mathrm{X}$ & & $\mathrm{X}$ & $\mathrm{X}$ & & & [106] \\
\hline Cylindrospermopsin & NRPS/PKS & $\mathrm{X}$ & $\mathrm{X}$ & $\mathrm{X}$ & & & & & & & & & $\mathrm{X}$ & [108] \\
\hline Fischerellin & PKS & & & & $\mathrm{X}$ & & & & & & & & & [111] \\
\hline Lyngbyatoxin-a & NRPS & & & & & & $X$ & & & & $\mathrm{X}$ & & & [108] \\
\hline Microcystin & NRPS/PKS & & & $\mathrm{X}$ & $\mathrm{X}$ & $\mathrm{X}$ & & $\mathrm{X}$ & & $\mathrm{X}$ & $\mathrm{X}$ & $\mathrm{X}$ & & {$[108,112,113]$} \\
\hline Microviridin & Ribosomal & & & $\mathrm{X}$ & & & & $\mathrm{X}$ & $X$ & $\mathrm{X}$ & & $\mathrm{X}$ & & {$[105,106]$} \\
\hline Microginin & NRPS & & & & & & & $\mathrm{X}$ & & $X$ & & $X$ & & {$[106]$} \\
\hline Nodularin & NRPS/PKS & & & & & & & & $X$ & & & & & [108] \\
\hline Saxitoxin & NRPS/PKS & $\mathrm{X}$ & $X$ & $\mathrm{X}$ & & & $\mathrm{X}$ & & & & & $\mathrm{X}$ & $\mathrm{X}$ & {$[108,114]$} \\
\hline
\end{tabular}

APHA Aphanizomenon, CYL Cylindrospermopsis, DOL Dolichospermum (formerly Anabaena), FISCH Fischerella, GLO Gloeotrichia, LYNG Lyngbya, MIC Microcystis, NOD Nodularia, NOST Nostoc, OSCIL Oscillatoria, PLANK Planktothrix, RAPH Raphidiopsis

participate in primary metabolic processes such as development, division, and repair. However, there is a growing body of research that indicates many of these compounds may be more critical to cell fitness than previously recognized. For example, a microcystin synthetase (mcy) gene knockout strain of Microcystis aeruginosa was found to be more sensitive to the effects of high light and oxidative stress relative to the wild-type [79•]. In the same study, microcystin was shown to intracellularly bind and protect proteins from the damaging effects of free oxygen radicals-providing the first evidence that this metabolite may be of primary importance for cell fitness. In another example, the genes involved in the biosynthesis of a posttranslationally modified novel tricyclic depsipeptide and presumed secondary metabolite microviridin, have been found in all 12 Microcystis genomes sequenced to date and have been identified in diverse other cyanobacteria $[80,81]$. Adding further evidence that this gene cluster may be of central importance to the ecology of these organisms, microviridin transcripts were among the most highly expressed across all 6 time points collected during a metatranscriptomic analysis of a cyanobacterial bloom sampled over a 24-hour period [82 0 . Additionally, transcripts from all 7 known NRPS/PKS clusters identified thus far in Microcystis spp. were observed over the study period, as well as 8 other cyanobacterial PKS/NRPS gene clusters. Strikingly, the most abundant transcripts detected throughout the study corresponded to an uncharacterized Microcystis NRPS/PKS operon, indicating there is still much to be learned from even the most thoroughly studied cyanobacteria. Finally, the observation that transcripts for all NRPS/PKS clusters were constitutively expressed throughout the light/dark cycle in that study suggests that these compounds are likely to be of central importance to the cell. Overall, this study highlighted the extent of genetic diversity present within a single Microcystis spp. bloom, as it contained much of the currently recognized global pangenome for this organism.

In a separate longitudinal investigation of a hypertrophic pond containing a cyanobacterial bloom (predominately Microcystis spp.), a metabolomic approach was used to screen for known and novel cyanobacterial secondary metabolites [83]. This study detected the presence of only 1 out of 73 known cyanobacterial protease inhibitors, but instead identified several unknown putative cyanobacterial-derived protease inhibitors. Combined, these results highlight the fact that the cyanobacterial pangenome is extraordinarily deep, and that as more attention is turned to cyanobacterial genomics and metabolomics, the list of newly discovered natural products and gene clusters will continue to grow. Moving forward, it seems there are 2 ways to approach managing these risks, either at the individual molecule level (ie, toxin screening), which is becoming increasingly more complex, or at the organismal level (ie, cell enumeration). 


\section{Managing Cyanobacterial-Impaired Waters-Public Health Implications}

Widespread eutrophication and hydrologic modification of surface waters, and the catalytic effects of global climate change, have enabled cyanobacterial blooms to become increasingly common fixtures in lakes and reservoirs around the world [84]. As such, enhanced surveillance is critical in order to mitigate exposure risks associated with these events. The World Health Organization has proposed a tiered response framework where alert levels are issued based on cyanobacterial cell or toxin concentrations, beginning at 2000 cells $/ \mathrm{mL}$ for drinking water or 20,000 cells/ $\mathrm{mL}$ for recreational waters - under the assumption that a range of $2-10 \mu \mathrm{g} / \mathrm{L}$ microcystin-LR may be observed when cyanobacterial populations reach 20,000 cells/mL [85]. However, the environmental range of cyanotoxins relative to cell concentrations remains inadequately evaluated due to the lack of standard methods for environmental sampling, processing, and analytical techniques used-all of which make data comparisons somewhat unreliable. Until more data are available, in order to maximize public health safety while maintaining cost considerations, we advocate for an adaptive management framework that incorporates toxin measurements only after potentially toxigenic cell densities exceed 2000 cells $/ \mathrm{mL}$. Although this level is subject to revision, we believe it is conservative and should be protective of human health based on data that are presently available. The incorporation of molecular methods, such as real-time quantitative PCR, can be used to specifically target toxin-producing genera, and this method should also enable high-throughput screening of samples at less cost and time than traditional microscope counts. Finally, public outreach and education should remain a key component of any CHAB management program. Although public perception data are scarce, a recent study in the United Kingdom estimated that only $27 \%-57 \%$ of the population thinks that CHAB exposures can negatively affect human health [86].

The U.S. Food and Drug Administration (FDA) has regulated seafood containing saxitoxins derived from marine dinoflagellates since 1995, although when the same toxins are produced by cyanobacteria in freshwater systems there is no federal regulatory oversight in place. Instead, management of cyanobacterial-impaired waters falls under the purview of the individual States; of which, less than half have developed any form of CHAB guidance. The EPA is aware of this growing problem; it listed cyanobacteria and their associated toxins on its second contaminant candidate list (CCL2) published in 2005 , and in 2009, 3 of the cyanotoxins (anatoxin-a, cylindrospermopsin, and microcystin) were placed onto the CCL3t. In making the contaminant candidate lists, the EPA reviewed approximately 7500 chemicals currently unregulated by the Safe Drinking Water Act (1996) but thought to occur in public water systems and designated 104 chemicals and 12 microbiological contaminants as worthy of further evaluation under their final CCL3 list. In 2007, the EPA conducted the first-ever baseline study of the condition of the nation's lakes $(n=1028)$ [87]. This study identified microcystins in approximately one-third of lakes, providing some insight into the pervasiveness of cyanobacteria nationally. As part of the Safe Drinking Water Act (1996) the EPA is required to monitor up to 30 currently unregulated contaminants in public drinking water supplies in order to assess their occurrence and to determine if regulation is warranted. In light of growing public awareness of cyanobacterial issues, and possibly due to a series of toxic $\mathrm{CHAB}$ events in high-profile systems such as Western Lake Erie [88], the EPA recently announced that it plans to begin monitoring specific cyanotoxins (anatoxin-a, cylindrospermopsin and the microcystin congeners MC-LR, YR, RR, LA) under its unregulated contaminant monitoring rule (UCMR, meeting 4), tentatively slated to begin in January 2018. Until then, it seems the sampling frequency and methods used by drinking water utilities to assess cyanotoxin health risks in raw and finished drinking waters will remain largely undisclosed. Fortunately, it seems many utilities are cognizant of cyanobacteria-related water impairment issues, and they are especially proactive in identifying and removing cyanobacterial-derived taste and odor causing compounds (geosmin and 2-methylisoborneol), which significantly degrade water quality aesthetics and are a common source of customer complaints $[89,90]$. Developing molecular assays that simultaneously detect both the taste and odor producing genes, as well as genes involved in toxin biosynthesis, could be one way to encourage adoption of a monitoring approach beneficial from both an economic and health perspective.

Considering the magnitude and pervasiveness of harmful algal blooms, management of this problem should be covered under the Safe Drinking Water Act and/or Clean Water Act (1972). The SDWA was designed to provide water treatment compliance, distribution system integrity, protection of source waters and public information about drinking water. The CWA was established to regulate the discharge of pollutants into U.S. waters and to create quality standards for surface waters. Due to the current absence of standardized analytical methods for cyanotoxin risk assessment, we propose that problematic cyanobacterial genera-including those outlined in Table 1 - be managed in a manner analogous to other EPA regulated pathogens, such as: Escherichia coli, Cryptosporidium parvum, and Giardia lamblia. That is to say, to regulate on a presence/absence basis of cyanobacterial markers in finished drinking water and by cell concentrations in surface waters. Microscope-based taxonomic assessments only need to be delineated down to the genus-level, since morphology is a poor indicator of toxicity [91]. Genetic markers targeting all freshwater $\mathrm{CHAB}$ genera could likewise be developed. The rationale for basing management decisions 
on cell abundances is that there are already too many toxins and toxin congeners to feasibly and effectively be managed on a per-toxin basis. Additionally, by framing regulatory decisions around assessments of cyanobacterial cell concentrations, unnecessary public health risks stemming from yet-tobe discovered bioactive molecules will also be mitigated. An estimate for what these limits should be can largely be derived from existing data that have been generated from investigations of the toxicological effects stemming from exposures to cyanobacterial crude extracts (homogenates) - which are often observed to be more lethal than exposure to the individual, purified toxins themselves [92-94]. These estimates could further be refined using high throughput bioassays incorporating mammalian cell lines [95], invertebrates [96], or fish embryos [97], for example, in order to tease apart the individual and synergistic effects of various cyanobacterial metabolites.

A universal definition for the Precautionary Principle (PP) does not currently exist, although its general context can be summarized as an impetus to mitigate biologically plausible threats to human health or the environment even though scientific consensus or absolute proof may not yet have been achieved. More simply stated, the goal of the principle is to protect human health before damage is done. For most of the major freshwater cyanotoxins (ie, anatoxin, cylindrospermopsin, microcystin, nodularin, and saxitoxin), the science has been advanced sufficiently to allow proactive management of these risks in waters used for drinking and recreation. However, when one considers the everexpanding assortment of bioactive metabolites produced by essentially all bloom-forming cyanobacteria-it becomes unclear what criteria should be satisfied in order to consider a bloom nontoxic, which is to say, safe for recreation and/or drinking water purposes. For example, Aphanizomenon flosaquae is commonly consumed as a health supplement because it is often considered nontoxic - although there are an increasing number of reports of it producing cylindrospermopsin and saxitoxin $[98,99]$. Additionally, in the only sequenced Aphanizomenon flos-aquae genome currently available, there were 4 NRPS/PKS gene clusters encoding for 3 unidentified metabolites and anabaenopeptin; the latter being considered nontoxic based on mouse studies. Therefore the list is up to a minimum of 6 different secondary metabolites that may be produced by Aph. flos-aquae strains, which raises the question: is it really safe to consider this organism suitable for human consumption when we know so little about it?

\section{Conclusions}

Overall, we see little reason to base health guidelines and management responses on species-level information, since cyanobacteria are highly recombinant and there is no reason to presume that a commonly nontoxic species cannot acquire toxigenic properties via horizontal gene transfer [100-103]. Until the time, costs and technical barriers involved in high throughput genome sequencing and analysis are alleviated, it is advisable to regulate cyanobacterial health risks on a cell concentration basis; ideally using a standardized method that incorporates a platform such as digital PCR, which quantifies the absolute DNA copy number of a target within a sample without requiring a calibration curve [104]. Additionally, this approach will enable quantification of toxigenic cells at concentrations presently below the limits of detection of analytical toxin measurements (eg, ELISA or LC/MS/MS), making it especially effective as an early sentinel for bloom initiation. Identification of the secondary metabolite-microviridin, in all Microcystis strains sequenced to date and in several other cyanobacterial genera [105] suggests that this compound may serve as a useful biomarker proxy for demonstrating adequate removal of cyanotoxins in finished drinking waters. As such, we propose a 'guilty-until-proven-innocent-approach' to CHAB management, consistent with the Precautionary Principle, in order to safeguard public health from both known and unknown cyanobacterial risks.

Acknowledgments The authors acknowledge the following support: the U.S. Geological Survey (2012OR127G), the U.S. National Science Foundation ENG/CBET (0826819), INSPIRE Program (1230543) and DEB (1240851) Dimension of Biodiversity Program, and the Nanjing Institute of Geography and Limnology, Chinese Academy of Sciences.

\section{Compliance with Ethics Guidelines}

Conflict of Interest Timothy G. Otten and Hans W. Paerl declare that they have no conflict of interest.

Human and Animal Rights and Informed Consent This article does not contain any studies with human or animal subjects performed by any of the authors.

\section{References}

Papers of particular interest, published recently, have been highlighted as:

- Of importance

1. Whitton BA, Potts M, editors. The ecology of cyanobacteria. Dordrecht: Kluwer Academic Publishers; 2000. p. 669.

2. Klemer AR, Cullen JJ, Mageau MT, Hanson KM, Sundell RA. Cyanobacterial buoyancy regulation: the paradoxical roles of carbon. J Phycol. 1996;32(1):47-53.

3. Paerl HW, Huisman J. Blooms like it hot. Science. 2008;320(5872): $57-8$.

4. Van de Waal DB, Verspagen JMH, Finke JF, Vournazou V, Immers AK, Kardinaal WEA, et al. Reversal in competitive dominance of a toxic versus non-toxic cyanobacterium in response to rising $\mathrm{CO}_{2}$. ISME J. 2011;5(9):1438-50. 
5. Verspagen JMH, Van de Waal DB, Finke JF, Visser PM, Donk EV, Huisman J. Rising $\mathrm{CO}_{2}$ levels will intensify phytoplankton blooms in eutrophic and hypertrophic lakes. PLoS One. 2014;9(8): e104325.

6. Paerl HW, Scott JT. Throwing fuel on the fire: synergistic effects of excessive nitrogen inputs and global warming on harmful algal blooms. Environ Sci Technol. 2010;44(20):7756-8.

7. Romo S, Soria J, Fernández F, Ouahid Y, Barón-Sola Á. Water residence time and the dynamics of toxic cyanobacteria. Freshw Biol. 2012;58(3):513-22.

8. Francis G. Poisonous Australian lake. Nature. 1878;18:11-2.

9. Edwards C, Beattie KA, Scrimgeour CM, Codd GA. Identification of anatoxin-a in benthic cyanobacteria (blue-green algae) and it associated dog poisonings at Lock Insh, Scotland. Toxicon. 1992;30:1167-75.

10. Carmichael WW, Azevedo SM, An SI, Molica RJ, Jochimsen EM, Lau S, et al. Human fatalities from cyanobacteria: chemical and biological evidence for cyanotoxins. Environ Health Perspect. 2001;109(7):663-8.

11. Stewart I, Seawright AA, Shaw GR. Cyanobacterial poisoning in livestock, wild mammals and birds - an overview. Adv Exp Med Biol. 2008;619:613-37.

12. Paerl HW, Otten TG. Blooms bite the hand that feeds them. Science. 2013;342(6157):433-4.

13. Stewart I, Schluter PJ, Shaw GR. Cyanobacterial lipopolysaccharides and human health — a review. Environ Health. 2006;5:7.

14. Stewart I, Webb PE, Schluter PJ, Shaw GR. Recreational and occupational field exposure to freshwater - a review of anecdotal and case reports, epidemiological studies and the challenges for epidemiologic assessment. Environ Health. 2006;5:6.

15. Giannuzzi L, Sedan D, Echenique R, Andrinolo D. An acute case of intoxication with cyanobacteria and cyanotoxins in recreational water in Salto Grande Dam, Argentina. Mar Drugs. 2011;9(11): 2164-75.

16. Funari E, Testai E. Human health risk assessment related to cyanotoxins exposure. Crit Rev Toxicol. 2008;38(2):97-125.

17. Hillborn ED, Roberts VA, Backer L, DeConno E, Egan JS, Hyde JB, et al. Algal bloom-associated disease outbreaks among users of freshwater lakes-United States, 2009-2010. MMWR. 2014;63(1):11-5.

18. Ibelings BW, Chorus I. Accumulation of cyanobacterial toxins in freshwater "seafood" and its consequences for public health: a review. Environ Pollut. 2007;150(1):177-92.

19. Miller MA, Kudela RM, Mekebri A, Crane D, Oates SC, Tinker MT, et al. Evidence for a novel marine harmful algal bloom: cyanotoxin (microcystin) transfer from land to Sea Otters. PLoS One. 2010;5(9):e12576.

20. Rankin KA, Alroy KA, Kudela RM, Oates SC, Murray MJ, Miller MA. Treatment of cyanobacterial (microcystin) toxicosis using oral cholestyramine: case report of a dog from Montana. Toxins. 2013;5(6):1051-63. Important because it provides the first experimental evidence for successful treatment of acute microcystin intoxication.

21. Jochimsen EM, Carmichael WW, An JS, Cardo DM, Cookson ST, Holmes CE, et al. Liver failure and death after exposure to microcystins at a hemodialysis center in Brazil. N Engl J Med. 1998;338(13):873-8

22. Griffiths DJ, Saker ML. The Palm Island Mystery disease 20 years on: a review of research on the cyanotoxin cylindrospermopsin. Environ Toxicol. 2003;18(2):78-93.

23. Zamyadi A, MacLeod SL, Fan Y, McQuaid N, Dorner S, Sauvé S, et al. Toxic cyanobacterial breakthrough and accumulation in a drinking water plant: a monitoring and treatment challenge. Water Res. 2012;46(5):1511-23.

24. Teixeira MR, Rosa MJ. Comparing dissolved air floatation and conventional sedimentation to remove cyanobacterial cells of
Microcystis aeruginosa: Part II. The effect of water background organics. Sep Purif Technol. 2007;53(1):126-34.

25. Teixeira MG, Sousa V, Rosa MJ. Investigating dissolved air flotation performance with cyanobacterial cells and filaments. Water Res. 2011;44(11):3337-44.

26. Rodríguez E, Onstad GD, Kull TPJ, Metcalf JS, Acero JL, von Gunten U. Oxidative elimination of cyanotoxins: comparison of ozone, chlorine, chlorine dioxide and permanganate. Water Res. 2007;41:3381-93.

27. Westrick JA, Szlag DC, Southwell BJ, Sinclair J. A review of cyanobacteria and cyanotoxins removal /inactivation in drinking water treatment. Anal Bioanal Chem. 2010;397:1705-14.

28. Orr PT, Jones GJ, Hamilton GR. Removal of saxitoxins from drinking water by granular activated carbon, ozone and hydrogen peroxide - implications for compliance with the Australian drinking water guidelines. Water Res. 2004;38(20):4455-61.

29. Ho L, Lambling P, Bustamante H, Duker P, Newcombe G. Application of powdered activated carbon for the adsorption of cylindrospermopsin and microcystin toxins from drinking water supplies. Water Res. 2011;45(9):2954-64.

30. Andrinolo D, Sedan D, Telese L, Aura C, Masera S, Giannuzzi L, et al. Hepatic recovery after damage produced by sub-chronic intoxication with the cyanotoxin microcystin-LR. Toxicon. 2008;51(3):457-67.

31. Chen J, Xie P, Xu J. First Identification of the hepatotoxic microcystins in the serum of a chronically exposed human population together with indication of hepatocellular damage. Toxicol Sci. 2009;108(1):81-9.

32. Carmichael WW. Cyanobacteria secondary metabolites - the cyanotoxins. J Appl Bacteriol. 1992;72(6):445-59.

33. Marahiel MA, Stachelhaus T, Mootz HD. Modular peptide synthases involved in nonribosomal peptide synthesis. Chem Rev. 1997;97:2651-74.

34. Ridley CP, Lee HL, Khosla C. Evolution of polyketide synthases in bacteria. Proc Natl Acad Sci U S A. 2008;105(12): 4595-600.

35. Mikalsen B, Boison G, Skulberg OM, Fastner J, Davies W, Gabrielsen TM, et al. Natural variation in the microcystin synthetase operon $m c y A B C$ and impact on microcystin production in Microcystis strains. J Bacteriol. 2003;185(9):2774-85.

36. Sano T, Takagi H, Nagano K, Nishikawa M, Kaya K. Accurate LCMS analyses for microcystins using per- $15^{\mathrm{N}}$-labeled microcystins. Anal Bioanal Chem. 2011;399:2511-16.

37. Pearson L, Mihali T, Moffitt M, Kellmann R, Neilan B. On the chemistry, toxicology and genetics of the cyanobacterial toxins, microcystin, nodularin, saxitoxin and cylindrospermopsin. Mar Drugs. 2010;8:1650-80.

38. Mazmouz R, Chapuis-Hugon F, Pichon V, Méjean A, Ploux O. The last step of the biosynthesis of the cyanotoxins cylindrospermopsin and 7-epi-cylindrospermopsin is catalyzed by Cyrl, a 2-oxoglutaratedependent iron oxygenase. Chem Bio Chem. 2011;12(6):858-62.

39. Chen YM, Lee TH, Lee SJ, Huang HB, Huang R, Chou HN. Comparison of protein phosphatase inhibition activities and mouse toxicities of microcystins. Toxicon. 2006;47(7):742-6.

40. Hitzfeld BC, Höger SJ, Dietrich DR. Cyanobacterial toxins: removal during drinking water treatment, and human risk assessment. Environ Health Perspect. 2000;108:113-22.

41. Rantala A, Fewer D, Hisbergues M, Rouhiainen L, Vaitomaa J, Börner T, et al. Phylogenetic evidence for the early evolution of microcystin synthesis. Proc Natl Acad Sci U S A. 2004;101: 568-73.

42. Eriksson JE, Toivola D, Meriluoto JA, Karaki H, Han YG, Hartshorne D. Hepatocyte deformation induced by cyanobacterial toxins reflects inhibition of protein phosphatases. Biochem Biophys Res Commun. 1990;173:1347-53. 
43. Runnegar MT, Berndt N, Kong SM, Lee EY, Zhang L. In vivo and in vitro binding of microcystin to protein phosphatases 1 and 2A. Biochem Biophys Res Commun. 1995;216:162-9.

44. Falconer IR, Humage AR. Tumour promotion by cyanobacteria. Phycologia. 1996;35:74-9.

45. Ueno $Y$, Nagata $S$, Tsutsumi $T$, Hasegawa A, Watanabe MF, Park $\mathrm{HD}$, et al. Detection of microcystins, a blue-green algal hepatotoxin, in drinking water sampled in Haimen and Fusui, endemic areas of primary liver cancer in China, by highly sensitive immunoassay. Carcinogenesis. 1996;17:1317-21.

46. Boyer GL, Sayler GS, Wilhelm SW. Global gene expression profiling in larval zebrafish exposed to microcystin-LR and Microcystis reveals endocrine disrupting effects of cyanobacteria. Environ Sci Technol. 2011;45:1962-9.

47. Fujiki H, Suganuma M. Tumor promoters-microcystin-LR, nodularin and TNF- $\alpha$ and human cancer development. Anticancer Agents Med Chem. 2011;11(1):4-18.

48. Li Y, Chen J, Zhao Q, Pu C, Qiu Z, Zhang R, et al. A crosssectional investigation of chronic exposure to microcystin in relationship to childhood liver damage in the Three Gorges Reservoir region, China. Environ Health Perspect. 2011;119:1483-8.

49. Honkanen RE, Dukelow M, Zwiller J, Moore RE, Khatra BS, Boynton AL. Cyanobacterial nodularin is a potent inhibitor of type 1 and type 2A protein phosphatases. Mol Pharmacol. 1991;40(4):577-83.

50. Ohta T, Sueoka E, Iida N, Komori A, Suganuma M, Nishiwaki R, et al. Nodularin, a potent inhibitor of protein phosphatases 1 and $2 \mathrm{~A}$, is a new environmental carcinogen in male F344 rat liver. Cancer Res. 1994;54:6402-6.

51. Shen X, Lam PK, Shaw GR, Wickramasinghe W. Genotoxicity investigation of a cyanobacterial toxin, cylindrospermopsin. Toxicon. 2002;40(10):1499-501.

52. Runnegar MT, Kong SM, Zhong YZ, Ge JL, Lu SC. The role of glutathione in the toxicity of a novel cyanobacterial alkaloid cylindrospermopsin in cultured rat hepatocytes. Biochem Biophys Res Comm. 1994;201:235-41.

53. Spivak CE, Witkop B, Albuquerque EX. Anatoxin-a: a novel, potent agonist at the nicotinic receptor. Mol Pharmacol. 1980;18(3):384-94.

54. Matsunaga S, Moore RE, Niemczura WP, Carmichael WW. Anatoxin-a(s), a potent anticholinesterase from Anabaena flosaquae. J Am Chem Soc. 1989;111(20):8021-3.

55. Méjean A, Paci G, Gautier V, Ploux O. Biosynthesis of anatoxin-a and analogues (anatoxins) in cyanobacteria. Toxicon. 2014 (In press). doi:10.1016/j.toxicon.2014.07.016.

56. Negri AP, Jones GJ. Bioaccumulation of paralytic shellfish poisoning (PSP) toxins from the cyanobacterium Anabaena circinalis by the freshwater mussel Alathyria condola. Toxicon. 1995;33(5): 667-78.

57. Wiese M, D'Agostino PM, Mihali TK, Moffitt MC, Neilan BA. Neurotoxic alkaloids: saxitoxin and its analogs. Mar Drugs. 2010;8:2185-211.

58. Viaggiu E, Melchiorre S, Volpi F, Corcia AD, Mancini R, Garibaldi L, et al. Anatoxin-a toxin in the cyanobacterium Planktothrix rubescens from a fishing pond in northern Italy. Environ Toxicol. 2004;19(3):191-7.

59. Vega A, Bell EA. $\alpha$-Amino- $\beta$-methylaminopropionic acid, a new amino acid from seeds of Cycas circinalis. Phytochemistry. 1967;6:759-62.

60. Holtcamp W. The emerging science of BMAA: do cyanobacteria contribute to neurodegenerative disease? Environ Health Perspect. 2013;120(3):a110-16.

61. Rao SD, Banack SA, Cox PA, Weiss JH. BMAA selectively injures motor neurons via AMPA/kainate receptor activation. Exp Neurol. 2006;201:244-52.
62. Chiu AS, Gehringer MM, Welch JH, Neilan BA. Does $\alpha$-Amino$\beta$-methylaminopropionic acid (BMAA) play a role in neurodegeneration? Int J Environ Res Public Health. 2011;8(9):3728-46.

63. Cox PA, Banack SA, Murch SJ. Biomagnification of cyanobacterial neurotoxins and neurodegenerative disease among the Chamorro people of Guam. Proc Natl Acad Sci U S A. 2003;100:13380-3.

64. Cox PA, Banack SA, Murch SJ, Rasmussen U, Tien G, Bidigare RR, et al. Diverse taxa of cyanobacteria produce $\beta$-N-methylamino-1alanine, a neurotoxic amino acid. Proc Natl Acad Sci U S A. 2005;102(14):5074-8.

65. Li A, Tian Z, Yu R, Banack SA, Wang Z. Detection of the neurotoxin BMAA within cyanobacteria isolated from freshwater in China. Toxicon. 2010;55(5):947-53.

66. Faassen EJ. Presence of the neurotoxin BMAA in aquatic ecosystems: what do we really know? Toxins. 2014;6(3):1109-38.

67. Marler TE, Snyder LR, Shaw CA. Cycas micronesica (Cycadales) plants devoid of endophytic cyanobacteria increase in betamethylamino-L-alanine. Toxicon. 2010;56(4):563-8.

68. Cohen SA. Analytical techniques for the detection of $\alpha$-amino- $\beta$ methylaminopropionic acid. Analyst. 2012;137:1991-2005.

69. Namikoshi M, Rinehart KL. Bioactive compounds produced by cyanobacteria. J Ind Microbiol Biotechnol. 1996;17:373-84.

70. Sivonen K, Leikoski N, Fewer DP, Jokela J. Cyanobactinsribosomal cyclic peptides produced by cyanobacteria. Appl Microbiol Biotechnol. 2010;86(5):1213-25.

71. Swan BK, Tupper B, Sczyrba A, Lauro FM, Martinez-Garcia M, González JM, et al. Prevalent genome streamlining and latitudinal divergence of planktonic bacteria in the surface ocean. Proc Natl Acad Sci U S A. 2013;110(28):11463-8.

72. Morris JJ, Lenski RE, Zinser ER. The Black Queen hypothesis: evolution of dependencies through adaptive gene loss. MBio. 2012;3(2):e00036-12.

73. Christiansen G, Dittmann E, Ordorika LV, Rippka R, Herdman M, Börner T. Nonribosomal peptide synthetase genes occur in most cyanobacterial genera as evidenced by their distribution in axenic strains of the PCC. Arch Microbiol. 2001;178:452-8.

74. Blin K, Medema MH, Kazempour D, Fischbach MA, Breitling R, Takano E, et al. antiSMASH 2.0-a versatile platform for genome mining of secondary metabolite producers. Nucleic Acids Res. 2013;41:W204-2012.

75. Kehr JC, Picchi DG, Dittmann E. Natural product biosyntheses in cyanobacteria: a treasure trove of unique enzymes. Beilstein J Org Chem. 2011;7:1622-35.

76. Shih PM, Wu D, Latifi A, Axen SD, Fewer DP, Talla E, et al. Improving the coverage of the cyanobacterial phylum using diversity-driven genome sequencing. Proc Natl Acad Sci U S A. 2013;110(3):1053-8. Important because it is the first large scale genome comparison study of diverse cyanobacterial genera.

77. Kaplan A, Harel M, Kaplan-Levy RN, Hadas O, Sukenik A, Dittmann E. The languages spoken in the water body (or the biological role of cyanobacterial toxins). Front Microbiol. 2012;3:1-11.

78. Holland A, Kinnear S. Interpreting the possible ecological role(s) of cyanotoxins: compounds for competitive advantage and/or physiological aide? Mar Drugs. 2013;11:2239-58.

79. Zilliges Y, Kehr JC, Meissner S, Ishida K, Mikkat S, Hagemann $\mathrm{M}$, et al. The cyanobacterial hepatotoxin microcystin binds to proteins and increases the fitness of Microcystis under oxidative stress conditions. PloS One. 2011;6(3):e17615. Important because it demonstrated that microcystins likely have an intracellular (protective) role in redox homeostasis.

80. Ziemert N, Ishida K, Weiz A, Hertweck C, Dittmann E. Exploiting the natural diversity of microviridin gene clusters for discovery of novel tricyclic depsipeptides. Appl Environ Microbiol. 2010;76(11):3568-74. 
81. Humbert JF, Barbe V, Latifi A, Gugger M, Calteau A, Coursin T, et al. A tribute to disorder in the genome of the bloom-forming freshwater cyanobacterium Microcystis aeruginosa. PLoS One. 2013;8(8):e70747.

82. Penn K, Wang J, Fernando SC, Thompson JR. Secondary metabolite gene expression and interplay of bacterial functions in a tropical freshwater cyanobacterial bloom. ISME J. 2014. doi:10.1038/ismej.2014.27. Important because it demonstrated that a variety of cyanobacterial NRPS/PKS gene clusters are highly expressed throughout the light and dark cycle, highlighting their importance to the cell.

83. Sadler T, Kuster C, Elert E. Seasonal dynamics of chemotypes in a freshwater phytoplankton community - a metabolomic approach. Harmful Algae. 2014;39:102-11.

84. Paerl HW, Huisman J. Climate change: a catalyst for global expansion of harmful cyanobacterial blooms. Environ Microbiol Rep. 2009;1(1):27-37.

85. Chorus I, Bartram J. Toxic cyanobacteria in water: a guide to their public health consequences, monitoring and management. World Health Organization, London (UK): E\&FN Spon; 1999.

86. Hunter PD, Hanley N, Czajkowski M, Mearns K, Tyler AN, Carvalho L, et al. The effect of risk perception on public preferences and willingness to pay for reduction in the health risks posed by toxic cyanobacterial blooms. Sci Total Environ. 2012;426:32-44.

87. U.S. Environmental Protection Agency. National lakes assessment: a collaborative survey of the nation's lakes. EPA 841-R09-001. Washington, DC: Office of Water and Office of Research and Development; 2009.

88. Michalak AM, Anderson EJ, Beletsky D, Boland S, Bosch NS, Bridgeman TB, et al. Record-setting algal bloom in Lake Erie caused by agricultural and meteorological trends consistent with expected future conditions. Proc Natl Acad Sci U S A. 2013;110(16):6448-52.

89. Jüttner F, Watson SB. Biochemical and ecological control of geosmin and 2-methylisoborneol in source waters. Appl Environ Microbiol. 2007;73(14):4395-406.

90. Srinivasan R, Sorial GA. Treatment of taste and odor causing compounds 2-methylisoborneol and geosmin in drinking water: a critical review. J Environ Sci. 2011;23(1):1-13.

91. Ouellette AJA, Wilhelm SW. Toxic cyanobacteria: the evolving molecular toolbox. Front Ecol Environ. 2003;1(7):359-66.

92. Oberemm A, Becker J, Codd GA, Steinberg C. Effects of cyanobacterial toxins and aqueous crude extracts of cyanobacteria on the development of fish and amphibians. Environ Toxicol. 1999;14(1):77-88.

93. Pietsch C, Wiegand C, Amé MV, Nicklisch A, Wunderlin D, Pflugmacher S. The effects of a cyanobacterial crude extract on different aquatic organisms: evidence for cyanobacterial toxin modulating factors. Environ Toxicol. 2001;16(6):535-42.

94. Burýsková B, Hilscherová K, Babica P, Vrsková D, Marsálek B, Bláha L. Toxicity of complex cyanobacterial samples and their fractions in Xenopus laevis embryos and the role of microcystins. Aquat Toxicol. 2006;80(4):346-54.

95. Froscio S, Sieburn K, Lau HM, Humpage A. Novel cytotoxicity associated with Anabaena circinalis 131C. Toxicon. 2011;58(8): 689-92.

96. Ferrão-Filho ADS, Soares MCS, de Magalhães VF, Azevedo SM. A rapid bioassay for detecting saxitoxins using a Daphnia acute toxicity test. Environ Pollut. 2010;158(6):2084-93.

97. Berry JP, Gantar M, Gibbs PDL, Schmale MC. The zebrafish (Danio rerio) embryo as a model system for identification and characterization of developmental toxins from marine and freshwater microalgae. Comparat Biochem Physiol Part C: Toxicol Pharmacol. 2007;145(1):61-72.

98. Preussel K, Stuken A, Wiedner C, Chorus I, Fastner J. First report on cylindrospermopsin producing Aphanizomenon flos-aquae (Cyanobacteria) isolated from two German lakes. Toxicon. 2006;47:156-62.

99. Zhang DL, Hu CX, Li DH, Liu YD. Zebrafish locomotor capacity and brain acetylcholinesterase activity is altered by Aphanizomenon flos-aquae DC-1 aphantoxins. Aquat Toxicol. 2013;138-9:139-49.

100. Zhaxybayeva O, Gogarten JP, Charlebois RL, Doolittle WF, Papke RT. Phylogenetic analyses of cyanobacterial genomes: quantification of horizontal gene transfer events. Genome Res. 2006;16:1099-108.

101. Leikoski N, Fewer DP, Sivonen K. Widespread occurrence and lateral transfer of the cyanobactin biosynthesis gene cluster in cyanobacteria. Appl Environ Microbiol. 2009;75(3):853-7.

102. Moustafa A, Loram JE, Hackett JD, Anderson DM, Plumley FG, Bhattacharya D. Origin of saxitoxin biosynthetic genes in cyanobacteria. PLoS One. 2009;4(6):e5758.

103. Sinha R, Pearson LA, Davis TW, Muenchhoff J, Pratama R, Jex $\mathrm{A}$, et al. Comparative genomics of Cylindrospermopsis raciborskii strains with differential toxicities. BMC Genomics. 2014;15:83.

104. Hindson BJ, Ness KD, Masquelier DA, Belgrader P, Heredia NJ, Makarewicz AJ, et al. High-throughput droplet digital PCR system for absolute quantitation of DNA copy number. Anal Chem. 2011;83:8604-10.

105. Philmus B, Christiansen G, Yoshida WY, Hemscheidt TK. Posttranslational modification in microviridin biosynthesis. Chembiochem. 2008;9(18):3066-73.

106. Welker M, von Döhren H. Cyanobacterial peptides - nature's own combinatorial biosynthesis. FEMS Microbiol Rev. 2006;30: 530-63.

107. Fewer DP, Jokela J, Paukku E, Österholm J, Wahlsten M, et al. New structural variants of aeruginosin produced by the toxic bloom forming cyanobacterium Nodularia spumigena. PLoS One. 2013;8(9):e73618.

108. Sivonen K, Börner T. Bioactive compounds produced by cyanobacteria. In: Herrero A, Flores E editors. The cyanobacteria: molecular biology, genomics and evolution. Norfolk: Caister Academic Press; 2008. p. 159-97.

109. Kaebernick M, Neilan BA. Ecological and molecular investigations of cyanotoxin production. FEMS Microbiol Ecol. 2001;35(1):1-9.

110. Wang H, Fewer DP, Sivonen K. Genome mining demonstrates the widespread occurrence of gene clusters encoding bacteriocins in cyanobacteria. PLoS One. 2011;6(7):e22384.

111. Hagmann L, Jütner F. Fischerellin A. A novel photosystem-IIinhibiting allelochemical of the cyanobacterium Fischerella muscicola with antifungal and herbicidal activity. Tetrahedron Lett. 1996;37:6529-42.

112. Cirés S, Alvarez-Roa C, Wood SA, Puddick J, Loza V, Heimann K. First report of microcystin-producing Fischerella sp. (Stigonematales, Cyanobacteria) in tropical Australia. Toxicon. 2014;88:62-6.

113. Carey CC, Haney JF, Cottingham KL. First report of microcystinLR in the cyanobacterium Gloeotrichia echinulata. Environ Toxicol. 2007;22(3):337-9.

114. Soto-Liebe K, Méndez MA, Fuenzalida L, Krock B, Cembella A, Vásquez M. PSP toxin release from the cyanobacterium Raphidiopsis brookii D9 (Nostocales) can be induced by sodium and potassium ions. Toxicon. 2012;60(17):1324-34. 